\section{Growth of Two Tropical Foliage \\ Plants Using \\ Coir Dust as a \\ Container \\ Medium \\ Amendment}

\author{
Alan W. Meerow ${ }^{1}$
}

Additional index words. potting media, nursery crops, sphagnum peat, sedge peat, Ravenea rivularis, Anthurium, 'Lady Jane', sustainable agriculture

Summary. Growth of Ravenea rivularis Jumelle and Perrier (majesty palm) and 'Lady Jane' Anthurium Schott was compared in container media, using as a primary organic component sphagnum peat, sedge peat, or coir dust. Growth index and shoot and root dry weights of majesty palm were significantly higher in the coir than the sedge peat medium. Growth index and shoot dry weight were only marginally higher for the anthurium in the coir vs. sedge peat medium, and root dry weights were comparable. Both crops grew equally well in the coir and the sphagnum peat medium. The sedge peat medium had the most air porosity and the least water-holding capacity of the three media at the initiation of the trials, but at termination showed a reversal of these parameters. The coir medium showed the least change in these parameters over 8 months. Highquality coir dust appears to be an acceptable substitute for sphagnum or sedge peat in soilless container media.

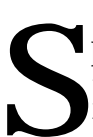
phagnum peat and sedge peat are the most common types of peat used in horticultural growing media, with sedge peat

${ }^{1}$ University of Florida, Institute of Food and Agricultural Sciences, Fort Lauderdale Research and Education Center, 3205 College Avenue, Fort Lauderdale, FL 33314.

Florida Agricultural Experiment Station Journal series no. R-04106. This work was supported in part by a grant from the EZ Soil Co., Idabel, Okla. The cost of publishing this paper was defrayed in part by the payment of page charges. Under postal regulations, this paper therefow must be hereby marked advertisement solely to indicate this fact. regarded as the inferior material due to its lack of uniformity and tendency to lose volume when wet (Bunt, 1988; Cresswell, 1992). Both are harvested from wetland ecosystems at rates considered" nonsustainable by wetland ecologists (Barber, 1993; Barkham, 1993; Buckland, 1993). While the peat industry argues that peatlands can be managed at sustainable levels (Robertson, 1993), it recognizes that alternatives to peat must be developed to meet environmental concerns of consumers and contend with increased regulation of peatland exploitation (Bragg, 1991; Robertson, 1993).

Coir pith or dust is the short fiber and dust left behind after the long fibers (coir) of the thick middle layer of the coconut fruit (Cocos nucifera L.) are extracted from husks and used in manufacturing. It is light to dark brown and consists primarily of 0.2 - to 2.0mm particles (75\% to $90 \%)$. It is primarily lignin (about 70\%) and cellulose (about $30 \%$ ), with a $\mathrm{C}: \mathrm{N}$ ratio of $80: 1$ (Meerow, 1994). Unlike sphagnum peat, it contains no sticks or other extraneous matter. Coir dust is hydrophilic relative to sphagnum peat and dehydrates readily (Cresswell, 1992).

The following qualities of coir dust recommend its use as an organic component in growing media (Cresswell, 1992):1) high water-holding capacity equal or superior to sphagnum peat, 2) excellent drainage equal to sphagnum peat, 3 ) absence of weeds and pathogens, 4) greater physical resiliency (withstands compression of baling better) than sphagnum peat, 5) renewable resource-no ecological drawbacks to its use, 6) decomposes more slowly than sedge or sphagnum peat, 7) acceptable $\mathrm{pH}$, cation-exchange capacity, and electrical conductivity, and 8) easier wetability than peat.

Excess $\mathrm{Cl}$ has been reported in coir dust from sources other than Sri Lanka (Cresswell, 1992; Handreck, 1993). Coir tends to be high in $\mathrm{Na}$ and K (Handreck, 1993) compared to the other peats, but $\mathrm{Na}$ is leached readily from the material under irrigation (Handreck, 1993). The most significant, but easily remedied, drawback to coir pith is variation in quality ii-em source to source (Handreck, 1993 ). So far, commercial operations in Sri Lanka (the world's leader in coir production) have established a high quality standard for use as a growing medium. 
Table 1. Growth of 'Lady Jane' Anthurium and Ravenea rivularis in coir-, sedge peat-, and sphagnum peat-based media.

\begin{tabular}{|c|c|c|c|c|}
\hline \multirow[b]{2}{*}{ Species } & \multirow[b]{2}{*}{ Medium } & \multirow{2}{*}{$\begin{array}{l}\text { Growth } \\
\text { index } \\
\text { (cm) }\end{array}$} & \multicolumn{2}{|c|}{$\begin{array}{c}\text { Dry wt } \\
\text { (g) }\end{array}$} \\
\hline & & & Shoot & Root \\
\hline \multirow{3}{*}{$\begin{array}{l}\text { Lady Jane Anthurium } \\
\qquad(\mathrm{n}=20)\end{array}$} & & & & \\
\hline & Coir & $58.30^{*}$ & $18.49^{*}$ & $10.61^{\mathrm{Ns}}$ \\
\hline & Sedge & 53.35 & 14.88 & 12.33 \\
\hline \multirow[t]{2}{*}{$(\mathrm{n}=15)$} & Coir & $52.73^{\mathrm{NS}}$ & $22.62^{\mathrm{NS}}$ & $12.93^{\mathrm{NS}}$ \\
\hline & Sphagnum & 57.06 & 24.03 & 12.12 \\
\hline \multicolumn{5}{|l|}{ Ravenea rivularis } \\
\hline \multirow[t]{2}{*}{$(\mathrm{n}=25)$} & Coir & $9.16^{* *}$ & $120.83^{* * *}$ & $53.35^{* *}$ \\
\hline & Sedge & 8.36 & 83.74 & 35.99 \\
\hline \multirow[t]{2}{*}{$(n=15)$} & Coir & $7.67^{\mathrm{Ns}}$ & $69.93^{\mathrm{NS}}$ & $21.40^{\mathrm{NS}}$ \\
\hline & Sphagnum & 7.53 & 75.71 & 22.81 \\
\hline
\end{tabular}

${ }^{2}$ Net increase in leaf number was used as the growtb index for Ravenea rivularis.

NS, * **,***Nons@@cant or significant at $P<0.05,0.005$, or 0.0005, respectively.
I previously reported on the growth-of two short-production-term (3 to 5 months) crops in a coir-based medium (Meerow, 1994). The objective of this study was to assess the performance of coir dust on two longerterm (8 months) tropical foliage crops.

\section{Materials and methods}

In the first experiment, 20 liners of 'Lady Jane' Anthurium and 25 liners of Ravenea rivularis (majesty palm) were potted into 1- and 2-gallon containers, respectively, of 5 aged but noncomposted pine bark : 4 sedge peat or coir pith : 1 coarse sand (by volume) on 13 Apr. 1993. In the second experiment; 15 liners of the same species were potted into 1-gallon containers of 5 aged but noncomposted pine bark : 4 sphagnum peat or coir pith : 1 coarse sand (by volume) on 8 Aug. 1993. All media were amended with $16 \mathrm{lb} / \mathrm{yd}^{3}\left(9.5 \mathrm{~kg} \cdot \mathrm{m}^{-3}\right)$ Osmocote $17 \mathrm{~N}-2.3 \mathrm{P}-10 \mathrm{~K} .(10$ to 14 months, Grace-Sierra, Milpitas, Calif.), $7 \mathrm{lb} /$ $\mathrm{yd}^{3}\left(4.16 \mathrm{~kg} \cdot \mathrm{m}^{-3}\right)$ dolomite, and $2 \mathrm{lb} /$ $\mathrm{y} \mathrm{d}^{3}\left(1.2 \mathrm{~kg} \cdot \mathrm{m}^{-3}\right)$ Micromax (GraceSierra). Replicate plants of each treatment were arranged in a completely randomized design under $63 \%$ shade [max photosynthetic photon flux (PPF) $=800 \mathrm{\mu mol} \cdot \mathrm{m}^{-2} \cdot \mathrm{s}^{-1}$, anthurium] or $50 \%$ shade $\left(\max \mathrm{PPF}=1100 \mu \mathrm{mol} \cdot \mathrm{m}^{-2} \cdot \mathrm{s}^{-1}\right.$, majesty palm) with daily overhead irrigation or rainfall. Height (base to highest point in canopy) and width (distance between widest two points in canopy) for each replication of anthurium were measured at inception and again at termination, from which a growth index was calculated (net change in height plus net change in width). For majesty palm, the most recently emerged leaf was tagged at inception, and number of leaves produced was used as the growth index. At termination, shoots and roots were harvested, dried, and weighed. The first experiment (coir vs. sedge peat) was terminated on 20 Dec 1993, and the second experiment (coir vs. sphagnum) was terminated on 20 Apr. 1994. Data were analyzed by analysis of variante. Physical parameters, $\mathrm{pH}$, and conductivity (EC) of the media were determined at inception and again at termination for three replicate l-gallon container samples of each medium exposed to the same growing conditions as the plants, but in which no plant was grown. The $\mathrm{pH}$ and $\mathrm{EC}$ were measured using the saturated paste extract method (Bunt, 1988 ). Physical parameters were determined in 1-galIon containers (column height $=12.5$ $\mathrm{cm}$ ) using protocols from Ingram et al. (1990). The coir dust used for this study (EZ Peat; EZ Soil Co., Idabel, Okla. ) originated in Sri Lanka and was received as highly compressed $20 \times 10$ $\times 5$-cm bricks. These were dehydrated according to manufacturer's instructions before incorporation into media.

\section{Results and discussion}

A coir-based medium produced a marginally higher growth index and shoot dry weight in the anthurium than in the same plant grown in sedge peat-based medium (Table 1). Root dry weights were statistically comparable, however. For majesty palm, all three growth parameters were significantly higher for plants grown in the coir-based medium (Table 1 ). For both crops, there was no significant difference in growth between plants produced in coir-based vs. sphagnumbased media (Table 1).

The sedge peat-based medium had the greatest percentage air space and the lowest water-holding capacity of the three media at the initiation of the trials, but at termination showed considerable reversal of these parameters (Table 2). The coir-based medium showed the least change over the 8 months of this study. The higher initial air porosity of the sedge-based medium may have been conducive to better initial root growth of the anthurium, as this plant is epiphytic in nature.

No evidence of $\mathrm{Cl}$ or $\mathrm{Na}$ toxicity was observed on the plants in this study grown in the coir-based medium, and EC measurements (Table 3) indicated low levels of total dissolved salts. The high $\mathrm{K}$ concentrations appeared to have no demonstra-
Table 2. Physical characteristics of coir-, sedge peat-, and sphagnum peat-based media. Mean $(S D)$ of three samples.

\begin{tabular}{|c|c|c|c|c|}
\hline \multirow[b]{2}{*}{ Medium } & \multicolumn{2}{|c|}{ Air space (\%) } & \multicolumn{2}{|c|}{ Water-holding capacity (\%) } \\
\hline & Initial & 8 months & Initial & 8 months \\
\hline Coir & $13.7(0.7)$ & $9.7(0.5)$ & $35.7(1.2)$ & $39.8(1.2)$ \\
\hline Sedge & $23.1(2.7)$ & $8.5(0.8)$ & $29.8(1.4)$ & $46.7(0.6)$ \\
\hline Sphagnum & $14.5(1.5)$ & $8.1(1.1)$ & $36.9(1.1)$ & $45.3(0.5)$ \\
\hline
\end{tabular}

Table 3. The $p H$ and electrical conductivity (EC) of coir-, sedge peat-, and sphagnum peat-based media. Mean (SD) of three samples.

\begin{tabular}{lccccc}
\hline & \multicolumn{2}{c}{$\mathrm{pH}$} & & \multicolumn{2}{c}{ EC $\left(\mathrm{dS} \cdot \mathrm{m}^{-1}\right)$} \\
\cline { 2 - 3 } \cline { 5 - 6 } Medium & Initial & & & 8 months & Initial \\
\hline Coir & $5.6(0.1)$ & $6.3(0.1)$ & & $3.1(1.3)$ & $0.31(0.13)$ \\
Sedge & $5.6(0.2)$ & $6.7(0.2)$ & & $2.4(1.5)$ & $0.40(0.07$ \\
Sphagnum & $4.9(0.1)$ & $6.3(0.2)$ & & $2.6(0.9)$ & $0.36(0.20)$ \\
\hline
\end{tabular}


bly negative affects and maybe a positive feature of the material.

These data largely confirm previous results with 'Starburst Pink' Pentas lanceolata (Forssk.) Defiers after 3 months, and, in part, 'Maui' Ixova coccinea L. after 5 months (Meerow, 1994). Both crops grew better in coir vs. sedge medium. Pentas grew equally well in coir and sphagnum peat medium. Growth index and shoot dry weight of Ixora were moderately lower in the coir-based medium than the sphagnum peat-based medium, although root dry weights were equal. This difference may have been caused by nitrogen draw-down in the coir medium (Cresswell, 1992; Handreck, 1993).

Based on the results reported here and elsewhere (Cresswell, 1992; Handreck, 1993, Labey, 1991; Meerow, 1994; Pryce, 1991; Radjagukguk et al., 1983; L. Smith, unpublished data; R. Wehl, unpublished data), high-quality coir dust appears to be an acceptable substitute for sphagnum or sedge peat in soilless container media, although nutritional regimes may need to be adjusted on a crop-by-crop basis. Coir pith is higher in $\mathrm{pH}$ than sphagnum (Cresswell, 1992; Handreck, 1993) (Table 3) and may require less liming for use in media. Coir dust already is used widely in Europe and Australia (Coghlan, 1992; Labey, 1991). The key issues in developing widespread use of this material in American horticulture will be price (currently equal to sphagnum peat) and ensuring consistent quality of the coir dusts that enter the marketplace.

\section{Literature Cited}

Barber, K.E. 1993. Peatlands as scientific archives of past biodiversity. Biodiv. Conserv. 2:474489

Barkham, J .P. 1993. For peat's sake: Conservation or exploitation? Biodiv. Conserv. 2:556566.

Bin., N.C. 1991. Peat and its alternatives. Hort. Dev. Council, Petersfield.

Buckland, P. 1993, Peatland archaeology: A conservation resource on the edge of extinction. Biodiv. Conserv. 2:513-527.

Bunt, A.C. 1988. Media and mixes for container-grown plants. Unwin Hyman, London.

Coghlan, A. 1992. Britain backs coconut composts. New Sci, 133:26.

Cresswell, G.C. 1992. Coir dust-A viable alternative to peat? p. 1-5 In: Proc. Austral. Potting Mix Manufacturers Conf., Sydney.

Handreck, K.A. 1993. Properties of coir dust, and its use in the formulation of soilless potting media. Commun. Soil Sci. Plant Anal. 24:349363.

Ingram, D.L., R.W. Henley, and T.H. Yeager. 1990. Diagnostic and monitoring procedures for nursery crops. Univ. of Florida Coop. Ext. Serv. Circ. 556.

Labey, B. 1991. Coir achieves peat performance. Hort. Week 24(18):15.

Merow, A. W. 1994. Growth of two subtropical ornamental using coir dust (coconut mesocarp pith) as a peat substitute, HortScience 29:14841486,

Pryce, S. 1991. Alternatives to peat. Pro. Hort. 5:101-106.

Radjagukguk, B., A. Soekotjo, H.O. Soeseno, and H.J . Santoso. 1983. A comparative study of peats and other media for containerised forest tree seedlings. Acts Hort. 150:449458.

Robertson, R.A. 1993. Peat, horticulture and environment, Biodiv. Conserv. 2:541-547. 